\title{
Does Inhaled Methoxyflurane Implement Fast and Efficient Pain Management in Trauma Patients? A Systematic Review and Meta-Analysis
}

\author{
Hong Liu $\cdot$ Xi Fu · Yi-Feng Ren (D) - Shi-Yan Tan · Si-Rui Xiang • \\ Chuan Zheng $\cdot$ Feng-Ming You $\cdot$ Wei Shi $\cdot$ Lin-Jiong Li
}

Received: February 8, 2021 / Accepted: March 16, 2021 / Published online: April 10, 2021

(C) The Author(s) 2021

\begin{abstract}
Introduction: Evidence on the use of inhaled methoxyflurane in the management of trauma pain is conflicting and obfuscated. This study aimed to determine the efficacy and safety of inhaled methoxyflurane for trauma pain on the basis of published randomized controlled trials (RCTs).

Methods: RCTs assessing the efficacy of methoxyflurane in adults or adolescents with acute trauma pain published in PubMed, Web of Science, Embase, Cochrane Library, and
\end{abstract}

Hong Liu and Xi Fu contributed equally as co-first authors.

Supplementary Information The online version contains supplementary material available at https:// doi.org/10.1007/s40122-021-00258-9.

H. Liu · X. Fu · Y.-F. Ren $(\bowtie) \cdot$ S.-Y. Tan .

S.-R. Xiang · C. Zheng · F.-M. You · L.-J. Li ( $\varangle)$

Hospital of Chengdu University of Traditional

Chinese Medicine, No. 39 Shi-er-qiao Road,

Chengdu 610072, Sichuan Province, China

e-mail: ryftcm.dr@yahoo.com

L.-J. Li

e-mail: lilinjiong@163.com

W. Shi $(\bowtie)$

Department of Anesthesiology, West China Hospital, Sichuan University and the Research Units of West China (2018RU012), Chinese Academy of Medical Sciences, Chengdu 610041, China e-mail: hxmzsw@126.com
Google Scholar were searched. The control groups were those that received placebo or standard analgesic treatment (SAT). The primary outcome was the change from baseline in pain scores during the first 30 min of treatment. Secondary outcomes included time to first pain relief, the proportion of patients experiencing pain relief, rescue analgesia rate, the treatment satisfaction of patients and investigators, and the methoxyflurane-related treatment-emergent adverse events (TEAEs).

Results: A total of nine RCTs (1806 patients) were identified. Results revealed that methoxyflurane provided a clinically unimportant benefit by improving the mean difference of change from baseline in pain intensity (from -0.44 to $-1.23 \mathrm{~cm}, p<0.001)$ at various time points within the first 20 min compared to control treatment. Besides, methoxyflurane decreased the time of onset of pain relief (mean difference - $5.29 \mathrm{~min}$; $95 \% \mathrm{CI}-6.97$ to -3.62 ) and the proportion of patients who needed rescue analgesic medication (risk ratio $1.41 ; 95 \% \mathrm{CI} 1.17-1.70$ ) despite it increasing the risk of non-severe TEAEs (risk ratio 3.09; 95\% CI 1.72-5.57). Notably, the benefit of almost all secondary pain-related outcomes was rendered clinically nonsignificant between methoxyflurane and SAT strata besides the time of onset of pain relief. The quality of evidence was low or very low in all outcomes.

Conclusions: In emergency situations without effective therapy, this systematic review and meta-analysis provides low-quality evidence that 
methoxyflurane can be used as a rapid-acting and effective treatment for acute trauma pain, although its utilization is associated a risk of nonsevere TEAEs. However, the current evidence does not support the notion that inhaled methoxyflurane offered superior analgesic efficacy to SAT.

Clinical Trial Number: PROSPERO registration number CRD42020223000.

Keywords: Methoxyflurane; Trauma pain Systematic review; Meta-analysis

\section{Key Summary Points}

\section{Why carry out this study?}

Several previously published reviews examining the effect of methoxyflurane have suggested benefit in emergency department patients, but definitive conclusions are limited by imprecision and non-quantitative analysis.

In addition, the results of methoxyfluranerelated adverse reactions in trauma patients are controversial, with conflicting trial results. With the recent publication of several high-quality trials, a specific pooled effect analysis aiming to evaluate the real effect of methoxyflurane was necessary.

\section{What was learned from the study?}

This meta-analysis was aimed at evaluating the efficacy and safety of inhaled methoxyflurane for trauma pain during emergency procedures.

The meta-analytic results provided lowquality evidence that methoxyflurane may be considered a simple, rapid-acting, and effective therapeutic option for acute trauma pain, despite the higher incidence of nonsevere treatment-emergent adverse events.

Compared to standard analgesic treatment, superiority of the analgesic advantage of methoxyflurane was not particularly pronounced. This finding is attributable to the drug onset time.

\section{DIGITAL FEATURES}

This article is published with digital features, including a summary slide, to facilitate understanding of the article. To view digital features for this article go to https://doi.org/10.6084/ m9.figshare.14216249.

\section{INTRODUCTION}

In hospital emergency departments (EDs), pain is one of the most common complaints presented by patients [1]. However, pain management in pre-hospital settings or in the ED is unsatisfactory $[2,3]$. Studies have documented that effective trauma pain management is very important for enhancing patient therapeutic compliance, quality of life, and satisfactory outcomes, which leads to shorter hospital stays $[4,5]$. Traditional pharmacotherapeutic options for acute pain in trauma settings include different kinds of opioid and non-opioid drugs (e.g., morphine, nitrous oxide, non-steroidal anti-inflammatory drugs) [6-8]. However, evidence suggests that these drugs confer an increased likelihood of bleeding, mood disorders, and death in trauma patients [9-11]. Thus, access to an effective therapeutic option with less severe adverse reactions is urgently required.

Methoxyflurane is a highly volatile halogenated ether that is administered through a portable inhaler [12]. Recently, the value of methoxyflurane at subanesthetic concentrations has continued to attract a lot of attention owing to its rapid analgesia and without significant nephrotoxicity [13-21]. On the basis of the results of the STOP! phase III trial [16], which demonstrated that methoxyflurane is effective and well tolerated in the management of acute trauma pain with a rapid onset of analgesia, it has been recommended by the European Society for Emergency Medicine as an emergency reliever of moderate-to-severe trauma pain in conscious adults [22]. In Australasia, methoxyflurane is also licensed for the management of trauma pain in adults and children [23]. 
Several previously published reviews examining the effect of methoxyflurane have suggested benefit in ED patients, but definitive conclusions are limited by imprecision and non-quantitative analysis [24-26]. A recently published article only summarized the completed or ongoing main studies in Europe without performing a systematic literature review [24]. In addition, the results of methoxyflurane-related adverse reactions in trauma patients are controversial, with conflicting trial results $[13,14,20,21]$. With the recent publication of several high-quality trials, a specific pooled effect analysis aiming to evaluate the real effect of methoxyflurane is necessary.

Therefore, we performed this meta-analysis of randomized controlled trials (RCTs) to evaluate the efficacy and safety of inhaled methoxyflurane for trauma pain. The change in pain intensity score at various time points within $30 \mathrm{~min}$ after the start of treatment was designated as the primary outcome. We also assessed the potential efficacy of methoxyflurane in patients of different age (adolescents vs adults) and the intervention of the control group (normal saline inhaled vs standard analgesic treatment, SAT) by a predefined subgroup analysis. Finally, we conducted a comprehensive evaluation of adverse drug reactions with the aim of gaining greater insights into the safety of methoxyflurane.

\section{METHODS}

\section{Search Strategy}

On the basis of the Preferred Reporting Items for Systematic Reviews and Meta-Analysis (PRISMA) guidelines and recommendations from the Cochrane Collaboration [27], a systematic search was performed in PubMed, Web of Science, Embase, and the Cochrane Central Register of Controlled Trials. Additionally, Google Scholar was used to retrieve gray literature. On December 27, 2020, this meta-analysis was registered on PROSPERO (CRD42020223000). We last updated our search on January 5, 2021 to ensure that there were no new trials that would meet the inclusion criteria for our study.

The search strategy was developed with the assistance of an information specialist. Keywords and free-text words associated with methoxyflurane, trauma pain, emergency department, pre-hospital, as well as the sensitive search strategy filter developed by Cochrane were used to identify RCTs. The full search strategy is shown in the supplementary material (eMethods 1-5). Furthermore, we searched ClinicalTrials.gov and the International Clinical Trial Registry Platform for completed and ongoing trials. A manual search was also performed in the reference lists of included studies and similar articles. Finally, we searched the Web of Science and EMBASE for conference proceedings.

\section{Eligibility Criteria and Study Selection}

We included RCTs if they involved patients with trauma pain who were randomized to methoxyflurane inhalation and compared to placebo or SAT; involved adolescents (at least 12 years of age) and adult patients with any type of trauma and who received methoxyflurane inhalation at any dose; and if they reported at least one of the following outcomes: change in pain scores at multiple time points, treatmentassociated adverse events, number of pain relief, or time of pain relief. Conference papers were included if we could extract accurate data that did not overlap with published studies. Studies that only presented protocols or did not have complete data were excluded. There were no language restrictions.

Two reviewers (HL and XF) independently screened the titles and abstracts. Full texts were subsequently reviewed for all potentially relevant studies. Any discrepancies were adjudicated by two other reviewers (YFR and LJL).

\section{Data Extraction}

Two authors (SYT and SRX) independently extracted the data using a standardized data extraction form. The extracted information included the name of the main author, the year 
of publication, the type of surgery, sample size, details of the intervention and control, and outcomes. Study authors were contacted for clarifications in case the population characteristics, follow-up method, or outcome data were unclear or not reported.

\section{Assessment of Methodology Quality and Risk of Bias}

Methodological quality of the included RCTs was independently reviewed by two reviewers (HL and XF). The Cochrane Collaboration's risk of bias tool was used [28]. The quality of each article was evaluated using seven domains (random sequence generation, allocation concealment, blinding of participants and personnel, blinding of outcome assessment, incomplete outcome data, selective reporting, and other bias). In case of disagreements, two reviewers (YFR and WS) discussed to reach a consensus. If one or more domains were found to be high, the overall assessment of the study would be considered as high risk of bias. A riskof-bias summary table was created in Review Manager, version 5.3. Additional details are included in the supplementary material (eTable 1, eFig. 1A, B).

Grades of Recommendation, Assessment, Development and Evaluation (GRADE) Profiler 3.6 software was used to evaluate the evidence quality for each outcome, which was classified as high $(\oplus \oplus \oplus \oplus)$, moderate $(\oplus \oplus \oplus \bigcirc)$, low $(\oplus \oplus \bigcirc \bigcirc)$, or very low $(\oplus \bigcirc \bigcirc \bigcirc)[29,30]$. Assessments included risk of bias, inconsistency, indirectness, imprecision, and other considerations $[29,30]$. Determination of evidence quality was performed by two independent reviewers (HL and XF) and any disagreements were resolved by consensus with other reviewers (WS and LJL).

\section{Measurement of Primary and Secondary Outcomes}

The primary outcome of this meta-analysis was the change in pain intensity score at $3,5,10,15$, 20,25 , and $30 \mathrm{~min}$ after the start of treatment. There were two types of pain score definitions: visual analogue scale (VAS) that ranged from 0 to 100,0 corresponding to no pain and 100 representing the worst imaginable pain; numeric rating scale (NRS) that ranged from 0 to $10,0=$ no pain and $10=$ unbearable pain . Pain intensities of all included studies were presented as a 10 -point scale $(0$, no pain; 10 , worst pain) by simple transformations [31, 32].

Secondary pain-related outcomes of this review include the time from the start of treatment to first pain relief (subjectively reported by the patient, in minutes), the proportion of patients experiencing pain relief until their departure from the ED (for definitions of pain relief in different studies, see supplementary material eTable 2), and the proportion of patients administered rescue analgesic medication until they were discharged from the ED.

Other secondary outcomes include the proportion of patients and investigators (physicians or nurse) who assessed the satisfactory factor and rated it as excellent, very good, or good, and the methoxyflurane-related treatment-emergent adverse events (TEAEs). Before ED discharge, satisfaction was measured using a five-point Likert scale (poor, fair, good, very good, excellent) [13]. The comprehensive evaluation indicators of methoxyflurane-related TEAEs were summarized and reported by the total incidence of TEAEs, the most common TEAEs occurring with methoxyflurane (dizziness, somnolence, feeling drunk, and headache), and system organ classes were defined according to the Medical Dictionary for Regulatory Activities [17]. All TEAEs were recorded from enrollment until ED discharge, with any subsequent TEAEs also being recorded at the follow-up visit on $14 \pm 2$ days.

\section{Statistical Analysis}

For all continuous effects, the mean \pm standard deviation (SD) was sought. If continuous variables were not presented as mean and SD, we contacted the corresponding author for the original data. If no response was received from the author, statistical conversions were conducted using the presented data. Specifically, the median and interquartile range were 
employed to approximate the mean and SD using the methods described by Wan et al. [33]. In situations where a mean and 95\% CI were given, conversions were made to a mean and SD using the methods defined by the Cochrane Collaboration [34]. Moreover, the SD was calculated by multiplying standard error by the square root of the number of patients [35]. Finally, data reported in graphical form were derived using the GetData Graph Digitizer Software (GetData Pty Ltd., Kogarah, Australia).

\section{Meta-Analysis}

Review Manager 5.3 (Cochrane Collaboration, Nordic Cochrane Centre, London, UK) was used for statistical analysis. Study weights for continuous variables were generated by the inverse variance method, and the Mantel-Haenszel method for dichotomous variables [36]. A weighted mean difference (WMD) with 99\% confidence interval (CI) was used for our primary outcome to decrease the risk of type I error associated with repeated testing, and a threshold for statistical significance (a two-sided $p$ value of $<0.01$ ) adjusted by the Bonferroni-Holm correction was considered statistically significant $[37,38]$. A negative mean difference implies that the methoxyflurane group, compared with the control group, had a higher magnitude of decrease in pain score between baseline and follow-up. For the continuous secondary outcome of the time to first pain relief, a WMD and 95\% CI was calculated; and for the dichotomous secondary outcomes including the proportion of pain relief, the proportion of rescue analgesic medication, the satisfaction assessment, and the incidence of TEAEs, a risk ratio (RR) with 95\% CI was calculated. A two-sided $p<0.05$ was considered statistically significant.

\section{Interpretation of Outcome Results}

For the change in pain intensity score at different time points after the start of treatment, the results were interpreted in light of the minimal clinically important difference in pain scores. This difference has been defined to be a
1.3- to $1.5-\mathrm{cm}$ change at a single time point for ED patients [39, 40]. Although not rigorously established, for the outcome of time from the start of treatment to first pain relief, we used a 4-min difference to interpret the treatment effect $[24,26]$.

\section{Heterogeneity, Sensitivity, and Subgroup Analysis}

$I^{2}$ statistics were used to assess the heterogeneity of the included studies. If $I^{2}<50 \%$, heterogeneity was considered not significant, and the fixed-effects model was applied; otherwise, we assumed that there was significant heterogeneity and used the random-effects model to calculate the effect size. If $I^{2}>50 \%$ was observed, sensitivity and subgroup analyses were performed to explore the sources of heterogeneity [34].

A priori sensitivity analysis was carried out by excluding the studies with a high risk of bias, and a post hoc sensitivity analysis was also conducted by excluding the results of the PenASAP trial [19]. The PenASAP findings were excluded because the procedures used SAT in both experimental and the normal saline groups, had the largest sample size, and declared that companies participated in the trial [19]; of note, this was explained by the authors in their introduction as an effort to investigate specific efficacy and safety data in the elderly population [19]. Additionally, we performed a predefined subgroup analysis based on baseline characteristics, namely age (adolescents vs adults) and the intervention of the control group (normal saline inhaled vs SAT). Notably, we did not perform subgroup analysis of methoxyflurane doses as they were consistent in all included studies, although planned in previous protocol registration. All non-prespecified analysis should be considered as exploratory.

\section{Assessment of Publication Biases}

For more than ten trials, a funnel plot is usually used to assess the possibility of publication bias. Although planned, we did not construct funnel 
plots to assess the publication bias for all outcomes as these are inaccurate when the number of included trials is less than ten $[41,42]$.

\section{Compliance with Ethics Guidelines}

This article is based on previously conducted studies and does not contain any new studies with human participants or animals performed by any of the authors.

\section{RESULTS}

From the 246 studies identified in our search, 93 duplicates were removed. A total of 153 studies had their titles and abstracts screened for eligibility. Of the resultant 153 citations, 119 were excluded on the basis of title and abstract alone, unrelated intervention or comparator $(n=76)$, incomplete study data $(n=30)$, or being an animal study $(n=13)$. The remaining 34 citations had their full-text reviewed. Of these, 25 were excluded because of irrelevant comparator $(n=2)$, not being an RCT $(n=20)$, and being a protocol without results $(n=3)$. Consequently, nine RCTs [13-21] involving a total of 1806 patients were found to be suitable for this metaanalysis. The search process is shown in Fig. 1. The authors of one of these studies reported potential conflicts of interest related to industry sponsorship [19].

\section{Characteristics of Included Studies}

Eight RCTs [13, 15-21] were multicentric, while one trial [14] was performed at a single center. Two studies [15, 17] belong to the subgroup analysis of the STOP! trial [16], while the data for two more studies [20, 21] were obtained from the MEDITA trial [18]. Two trials [16, 17] involved adolescents while the remaining seven trials [13-15, 18-21] only involved adults. All trials [13-21] enrolled patients presenting with any trauma severity treated at a hospital ED. The majority of the included patients exhibited moderate-to-severe trauma, but three studies investigated patients with severe pain [14], moderate pain [15], and minor-to-moderate pain [16] (see Table 1 for more details regarding trauma severity from included trials). Specification of the methoxyflurane dosage was the same for all the included trials with the most common regimen being a Penthrox ${ }^{\circledR}$ inhaler (containing $3 \mathrm{~mL}$ methoxyflurane). However, the intervention methods of the control group varied among studies: four trials [15-17, 19] were normal saline controlled, while five trials $[13,14,18,20,21]$ used different SAT modes. Specially, one study [19] added the SAT in both experimental and normal saline groups. Detailed characteristics of all the included studies are shown in Table 1.

\section{Risk of Bias}

The risk of bias assessment for all nine studies can be viewed in the supplemental material (eTable 2, eFig. 1A, B). The overall risk of bias was low in four double-blind RCTs $[15-17,19]$, and high in five open label trials $[13,14,18,20,21]$ because participants or investigators were not blinded. All included trials exhibited prespecified outcomes. Randomization sequences and concealed allocation were adequately generated in all studies. Three trials $[18,20,21]$ had an unclear risk of other bias that was attributed to a lack of sufficient methodological reports.

\section{Primary Outcomes}

Seven trials $[13,15-18,20,21]$ reported on the change in pain intensity score within $30 \mathrm{~min}$ after the start of treatment. Pain intensity change was reported using a 100-point VAS (six studies, $n=1028)[15-18,20,21]$ or NRS (1 study, $n=305$ ) [13], which was converted to a 10-point scale. One of the seven trials was not included in the meta-analysis because we were unable obtain the original data from graphs [20]. Changes in pain intensities were analyzed several times from baseline to $3 \mathrm{~min}$ (three studies, $n=668$ ) $[13,18,21], 5 \mathrm{~min}$ (six studies, $n=1264$ ) [13, 15-18, 21], $10 \mathrm{~min}$ (six studies, $n=1264$ ) [13, 15-18, 21], $15 \mathrm{~min}$ (six studies, $n=1264$ ) [13, 15-18, 21], $20 \mathrm{~min}$ (six studies, $n=1264$ ) $[13,15-18,21], 25 \mathrm{~min}$ (two studies, 


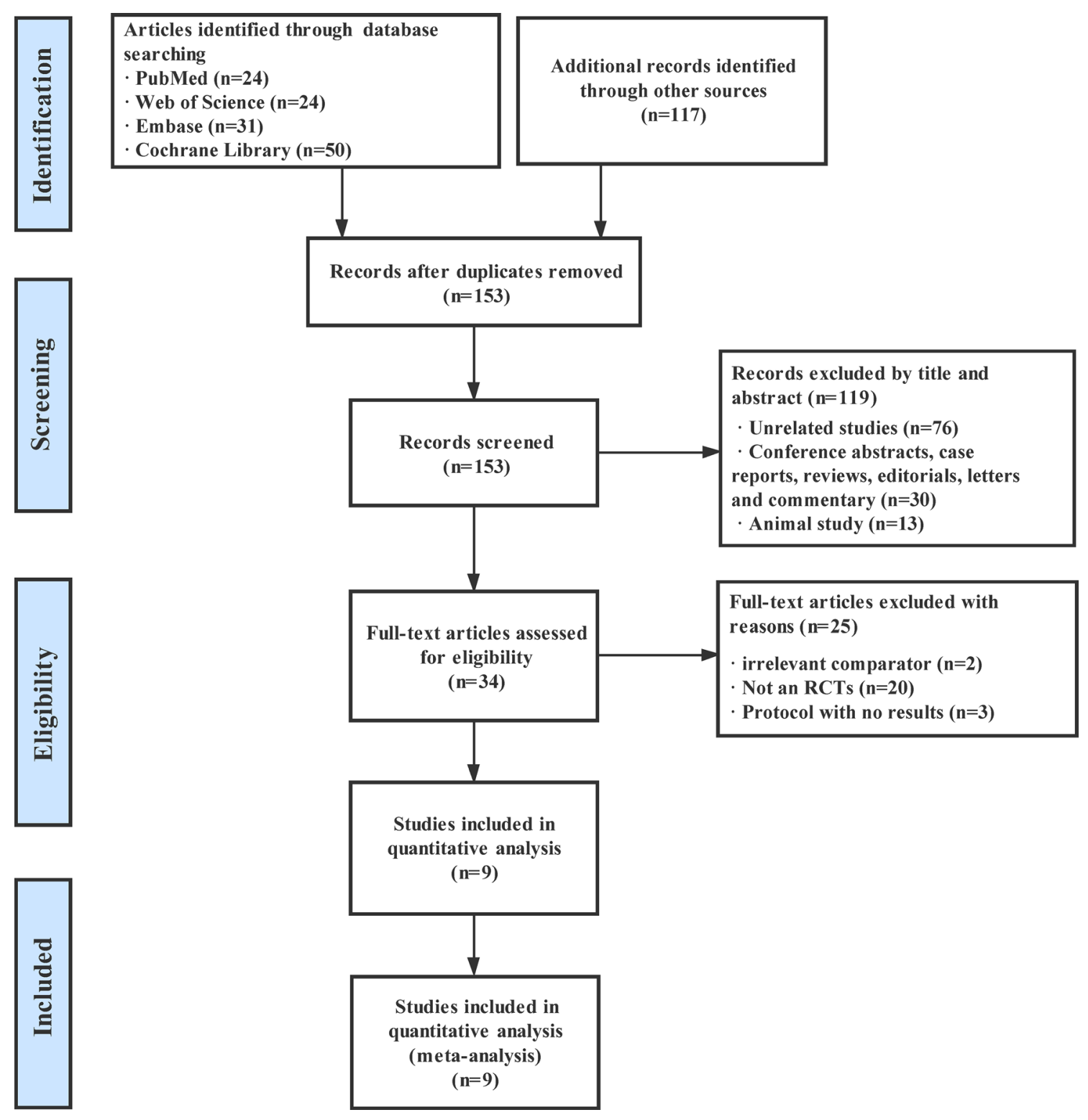

Fig. 1 Study flowchart

$n=363$ ) [18, 21], and $30 \mathrm{~min}$ (two studies, $n=363)[18,21]$ to assess the pooled effects.

Participants administered methoxyflurane exhibited larger mean reduction from baseline in pain intensity score than the control group at $3 \mathrm{~min}$ (WMD $-0.44 \mathrm{~cm}$; 99\% CI -0.64 , $\left.-0.23 ; p<0.00001 ; I^{2}=0 \%\right), 5 \mathrm{~min}$ (WMD $-0.93 \mathrm{~cm} ; 99 \% \mathrm{CI}-1.14,-0.71 ; p<0.00001$; $\left.I^{2}=28 \%\right), 10 \mathrm{~min}(\mathrm{WMD}-1.11 \mathrm{~cm} ; 99 \% \mathrm{CI}$ $\left.-1.56,-0.66 ; p<0.00001 ; I^{2}=65 \%\right), 15 \mathrm{~min}$ (WMD $-1.23 \mathrm{~cm} ; 99 \%$ CI $-1.99,-0.47$; $p<0.0001 ; \quad I^{2}=85 \%$ ), and $20 \mathrm{~min} \quad(\mathrm{WMD}$ $-1.12 \mathrm{~cm} ; 99 \%$ CI $-1.75,-0.49 ; p<0.00001$; $\left.I^{2}=75 \%\right)$. Changes in pain intensity did not differ between groups at $25 \mathrm{~min}$ (WMD $-0.36 \mathrm{~cm} ; \quad 99 \%$ CI $-0.85,0.31 ; p=0.06$; $I^{2}=3 \%$ ) and $30 \mathrm{~min}(\mathrm{WMD}-0.39 \mathrm{~cm} ; 99 \% \mathrm{CI}$ - 0.97, 0.19; $p=0.08 ; I^{2}=0 \%$ ) (Figs. 2, 3a, b). These differences failed to meet the threshold for clinical significance (a 1.3- to 1.5-cm change at any single time point). 
Table 1 Baseline characteristics of included studies

\begin{tabular}{|c|c|c|c|c|c|c|}
\hline Study & $\begin{array}{l}\text { Study } \\
\text { design }\end{array}$ & Study population & $\begin{array}{l}\text { Methoxyflurane } \\
\text { group }(n)\end{array}$ & $\begin{array}{l}\text { Control group } \\
(n)\end{array}$ & $\begin{array}{l}\text { Primary } \\
\text { outcome }\end{array}$ & $\begin{array}{l}\text { Secondary } \\
\text { outcome }\end{array}$ \\
\hline $\begin{array}{c}\text { Borobia } \\
{[13]}\end{array}$ & $\begin{array}{c}\text { Multisite } \\
\text { RCT }\end{array}$ & $\begin{array}{l}\text { Age } \geq 18 \text { years; } \\
\text { trauma with } \\
\text { moderate-to- } \\
\text { severe acute pain } \\
\text { treated at a } \\
\text { hospital ED } \\
(\mathrm{NRS} \geq 4)\end{array}$ & $\begin{array}{c}3 \mathrm{~mL} \text { inhaled } \\
\text { dose (156) }\end{array}$ & $\begin{array}{l}\text { SAT: NSAIDs } \\
\text { for moderate } \\
\text { pain; } \\
\text { nonopioid } \\
\text { and opioid for } \\
\text { severe pain } \\
(149)\end{array}$ & $\begin{array}{l}\text { Change in } \\
\text { NRS scores } \\
\text { at } 3,5,10 \\
15,20 \mathrm{~min}\end{array}$ & $\begin{array}{l}\text { (1) Time from } \\
\text { the start of } \\
\text { treatment to } \\
\text { first pain } \\
\text { relief } \\
\text { (2) Number of } \\
\text { first pain } \\
\text { relief } \\
\text { (3) Proportion } \\
\text { of rescue } \\
\text { analgesic } \\
\text { medication } \\
\text { (4) TEAEs } \\
\text { (5) Satisfaction } \\
\text { measurement } \\
\text { of patients }\end{array}$ \\
\hline $\begin{array}{c}\text { Brichko } \\
{[14]}\end{array}$ & $\begin{array}{l}\text { Single-site } \\
\text { RCT }\end{array}$ & $\begin{array}{l}\text { Age } 18-75 \text { years; } \\
\text { trauma with } \\
\text { severe acute pain } \\
\text { treated at a } \\
\text { hospital ED } \\
(\mathrm{NRS} \geq 8)\end{array}$ & $\begin{array}{c}3 \mathrm{~mL} \text { inhaled } \\
\text { dose }(60)\end{array}$ & $\begin{array}{l}\text { SAT: } \\
\text { multimodal } \\
\text { approach } \\
\text { including } \\
\text { nonopioid } \\
\text { and opioid } \\
(60)\end{array}$ & $\begin{array}{l}\text { Number of } \\
\text { pain relief } \\
\text { (reduction } \\
\text { of NRS } \\
\text { score } \\
\text { by } \geq 50 \% \text { ) }\end{array}$ & $\begin{array}{l}\text { (1) NRS scores } \\
\text { at } 15,30,60 \text {, } \\
90 \text { min (no } \\
\text { baseline } \\
\text { value) } \\
\text { (2) TEAEs (no } \\
\text { specific data) }\end{array}$ \\
\hline Coffey [15] & $\begin{array}{c}\text { Multisite } \\
\text { RCT }\end{array}$ & $\begin{array}{l}\text { Age } \geq 12 \text { years; } \\
\text { trauma with } \\
\text { minor-to- } \\
\text { moderate acute } \\
\text { pain treated at a } \\
\text { hospital ED } \\
(1 \leq \mathrm{NRS}<7)\end{array}$ & $\begin{array}{c}3 \mathrm{~mL} \text { inhaled } \\
\text { dose (149) }\end{array}$ & $\begin{array}{l}5 \mathrm{~mL} \text { normal } \\
\text { saline inhaled } \\
(149)\end{array}$ & $\begin{array}{l}\text { Change in } \\
\text { VAS scores } \\
\text { at } 5,10,15 \text {, } \\
20,30 \mathrm{~min}\end{array}$ & $\begin{array}{l}\text { (1) Time from } \\
\text { the start of } \\
\text { treatment to } \\
\text { first pain } \\
\text { relief } \\
\text { (2) Proportion } \\
\text { of rescue } \\
\text { analgesic } \\
\text { medication } \\
\text { (3) TEAEs } \\
\text { (4) Satisfaction } \\
\text { measurement } \\
\text { of patients, } \\
\text { physician, and } \\
\text { nurse }\end{array}$ \\
\hline
\end{tabular}


Table 1 continued

\begin{tabular}{|c|c|c|c|c|c|c|}
\hline Study & $\begin{array}{l}\text { Study } \\
\text { design }\end{array}$ & Study population & $\begin{array}{l}\text { Methoxyflurane } \\
\text { group }(n)\end{array}$ & $\begin{array}{l}\text { Control group } \\
(n)\end{array}$ & $\begin{array}{l}\text { Primary } \\
\text { outcome }\end{array}$ & $\begin{array}{l}\text { Secondary } \\
\text { outcome }\end{array}$ \\
\hline Coffey [16] & $\begin{array}{l}\text { Subgroup } \\
\text { analysis } \\
\text { of } \\
\text { multisite } \\
\text { RCT }\end{array}$ & $\begin{array}{l}\text { Age } \geq 18 \text { years; } \\
\text { trauma with } \\
\text { moderate acute } \\
\text { pain treated at a } \\
\text { hospital ED } \\
(4 \leq \mathrm{NRS}<7)\end{array}$ & $\begin{array}{c}3 \mathrm{~mL} \text { inhaled } \\
\text { dose (102) }\end{array}$ & $\begin{array}{l}5 \mathrm{~mL} \text { normal } \\
\text { saline inhaled } \\
(101)\end{array}$ & $\begin{array}{l}\text { Change in } \\
\text { VAS scores } \\
\text { at } 5,10,15 \text {, } \\
20 \mathrm{~min}\end{array}$ & $\begin{array}{l}\text { (1) Time from } \\
\text { the start of } \\
\text { treatment to } \\
\text { first pain } \\
\text { relief } \\
\text { (2) Number of } \\
\text { first pain } \\
\text { relief } \\
\text { (3) Proportion } \\
\text { of rescue } \\
\text { analgesic } \\
\text { medication } \\
\text { (4) TEAEs } \\
\text { (5) Satisfaction } \\
\text { measurement } \\
\text { of patients, } \\
\text { physician, and } \\
\text { nurse }\end{array}$ \\
\hline $\begin{array}{c}\text { Hartshorn } \\
{[17]}\end{array}$ & $\begin{array}{l}\text { Subgroup } \\
\text { analysis } \\
\text { of } \\
\text { multisite } \\
\text { RCT }\end{array}$ & $\begin{array}{l}\text { Age } 12-17 \text { years; } \\
\text { trauma with } \\
\text { moderate-to- } \\
\text { severe acute pain } \\
\text { treated at a } \\
\text { hospital ED } \\
(\mathrm{NRS} \geq 4)\end{array}$ & $\begin{array}{c}3 \mathrm{~mL} \text { inhaled } \\
\text { dose }(47)\end{array}$ & $\begin{array}{l}5 \mathrm{~mL} \text { normal } \\
\text { saline inhaled } \\
(48)\end{array}$ & $\begin{array}{l}\text { Change in } \\
\text { VAS scores } \\
\text { at } 5,10,15 \text {, } \\
20 \mathrm{~min}\end{array}$ & $\begin{array}{l}\text { (1) Time from } \\
\text { the start of } \\
\text { treatment to } \\
\text { first pain } \\
\text { relief } \\
\text { (2) Number of } \\
\text { first pain } \\
\text { relief } \\
\text { (3) Proportion } \\
\text { of rescue } \\
\text { analgesic } \\
\text { medication } \\
\text { (4) TEAEs } \\
\text { (5) Satisfaction } \\
\text { measurement } \\
\text { of patients, } \\
\text { physician, and } \\
\text { nurse }\end{array}$ \\
\hline
\end{tabular}


Table 1 continued

\begin{tabular}{|c|c|c|c|c|c|c|}
\hline Study & $\begin{array}{l}\text { Study } \\
\text { design }\end{array}$ & Study population & $\begin{array}{l}\text { Methoxyflurane } \\
\text { group }(n)\end{array}$ & $\begin{array}{l}\text { Control group } \\
(n)\end{array}$ & $\begin{array}{l}\text { Primary } \\
\text { outcome }\end{array}$ & $\begin{array}{l}\text { Secondary } \\
\text { outcome }\end{array}$ \\
\hline $\begin{array}{l}\text { Mercadante } \\
{[18]}\end{array}$ & $\begin{array}{c}\text { Multisite } \\
\text { RCT }\end{array}$ & $\begin{array}{l}\text { Age } \geq 18 \text { years; } \\
\text { trauma with } \\
\text { moderate-to- } \\
\text { severe acute pain } \\
\text { treated at a } \\
\text { hospital ED } \\
(\mathrm{NRS} \geq 4)\end{array}$ & $\begin{array}{c}3 \mathrm{~mL} \text { inhaled } \\
\text { dose (135) }\end{array}$ & $\begin{array}{l}\text { SAT: } \\
\text { paracetamol } \\
\text { or ketoprofen } \\
\text { for moderate } \\
\text { pain; } \\
\text { morphine for } \\
\text { severe pain } \\
(135)\end{array}$ & $\begin{array}{l}\text { Change in } \\
\text { VAS scores } \\
\text { at } 3,5,10, \\
15,20,25, \\
30 \mathrm{~min}\end{array}$ & $\begin{array}{l}\text { (1) Time from } \\
\text { the start of } \\
\text { treatment to } \\
\text { first pain } \\
\text { relief } \\
\text { (2) Number of } \\
\text { first pain } \\
\text { relief } \\
\text { (3) Proportion } \\
\text { of rescue } \\
\text { analgesic } \\
\text { medication } \\
\text { (4) TEAEs } \\
\text { (5) Satisfaction } \\
\text { measurement } \\
\text { of patients } \\
\text { and physician }\end{array}$ \\
\hline $\begin{array}{l}\text { Ricard- } \\
\text { Hibon } \\
{[19]}\end{array}$ & $\begin{array}{c}\text { Multisite } \\
\text { RCT }\end{array}$ & $\begin{array}{l}\text { Age } \geq 18 \text { years; } \\
\text { trauma with } \\
\text { moderate-to- } \\
\text { severe acute pain } \\
\text { treated at a } \\
\text { hospital ED } \\
(\mathrm{NRS} \geq 4)\end{array}$ & $\begin{array}{l}3 \mathrm{~mL} \text { inhaled } \\
\text { dose plus SAT } \\
(178)^{\mathrm{a}}\end{array}$ & $\begin{array}{l}5 \mathrm{~mL} \text { normal } \\
\text { saline inhaled } \\
\text { plus SAT } \\
(173)^{\mathrm{a}}\end{array}$ & $\begin{array}{l}\text { Time from the } \\
\text { start of } \\
\text { treatment to } \\
\text { pain relief } \\
\text { (insufficient } \\
\text { data) }\end{array}$ & $\begin{array}{l}\text { (1) Number of } \\
\text { first pain } \\
\text { relief } \\
\text { (2) TEAEs } \\
\text { (3) Satisfaction } \\
\text { measurement } \\
\text { of patients, } \\
\text { physician, and } \\
\text { nurse }\end{array}$ \\
\hline
\end{tabular}


Table 1 continued

\begin{tabular}{|c|c|c|c|c|c|c|}
\hline Study & $\begin{array}{l}\text { Study } \\
\text { design }\end{array}$ & Study population & $\begin{array}{l}\text { Methoxyflurane } \\
\text { group }(n)\end{array}$ & $\begin{array}{l}\text { Control group } \\
(n)\end{array}$ & $\begin{array}{l}\text { Primary } \\
\text { outcome }\end{array}$ & $\begin{array}{l}\text { Secondary } \\
\text { outcome }\end{array}$ \\
\hline Serra [20] & $\begin{array}{l}\text { Subgroup } \\
\text { analysis } \\
\text { of } \\
\text { multisite } \\
\text { RCT }\end{array}$ & $\begin{array}{l}\text { Age } \geq 65 \text { years; } \\
\text { trauma with } \\
\text { moderate-to- } \\
\text { severe acute pain } \\
\text { treated at a } \\
\text { hospital ED } \\
(\mathrm{NRS} \geq 4)\end{array}$ & $\begin{array}{c}3 \mathrm{~mL} \text { inhaled } \\
\text { dose (35) }\end{array}$ & $\begin{array}{l}\text { SAT: } \\
\text { paracetamol } \\
\text { or ketoprofen } \\
\text { for moderate } \\
\text { pain; } \\
\text { morphine for } \\
\text { severe pain } \\
(34)\end{array}$ & $\begin{array}{l}\text { Change in } \\
\text { VAS scores } \\
\text { at } 3,5,10 \text {, } \\
\begin{array}{l}15,20,25, \\
30 \mathrm{~min}\end{array}\end{array}$ & $\begin{array}{l}\text { (1) Time from } \\
\text { the start of } \\
\text { treatment to } \\
\text { first pain } \\
\text { relief } \\
\text { (2) Number of } \\
\text { first pain } \\
\text { relief } \\
\text { (3) Proportion } \\
\text { of rescue } \\
\text { analgesic } \\
\text { medication } \\
\text { (4) Adverse } \\
\text { events (not } \\
\text { TEAE) } \\
\text { (5) Satisfaction } \\
\text { measurement } \\
\text { of patients } \\
\text { and physician }\end{array}$ \\
\hline Voza [21] & $\begin{array}{l}\text { Subgroup } \\
\text { analysis } \\
\text { of } \\
\text { multisite } \\
\text { RCT }\end{array}$ & $\begin{array}{l}\text { Age } \geq 18 \text { years; } \\
\text { trauma with } \\
\text { moderate-to- } \\
\text { severe acute pain } \\
\text { treated at a } \\
\text { hospital ED } \\
(\mathrm{NRS} \geq 4)\end{array}$ & $\begin{array}{c}3 \mathrm{~mL} \text { inhaled } \\
\text { dose (49) }\end{array}$ & $\begin{array}{l}\text { SAT: } \\
\text { paracetamol } \\
\text { or ketoprofen } \\
\text { for moderate } \\
\text { pain; } \\
\text { morphine for } \\
\text { severe pain } \\
(44)\end{array}$ & $\begin{array}{l}\text { Change in } \\
\text { VAS scores } \\
\text { at } 3,5,10 \text {, } \\
15,20,25, \\
30 \mathrm{~min}\end{array}$ & $\begin{array}{l}\text { (1) Time from } \\
\text { the start of } \\
\text { treatment to } \\
\text { first pain } \\
\text { relief } \\
\text { (2) Proportion } \\
\text { of rescue } \\
\text { analgesic } \\
\text { medication } \\
\text { (3) TEAEs } \\
\text { (4) Satisfaction } \\
\text { measurement } \\
\text { of patients } \\
\text { and physician }\end{array}$ \\
\hline
\end{tabular}

$n$ number of patients, NSAIDs non-steroidal anti-inflammatory drugs, $R C T$ randomized controlled trial, $E D$ emergency department, $S A T$ standard analgesic treatment, NRS numeric rating scales, $V A S$ visual analogue scale, TEAEs treatmentemergent adverse events

a Any type and route of analgesic was permitted according to the protocol in each center, except strong oral opioids and analgesics administered intranasally 





4Fig. 2 Forest plots of the change in pain intensity score at different times within $30 \mathrm{~min}$ after the start of treatment. SD standard deviation, IV inverse-variance method, $\mathrm{Tau}^{2}$ a variance of the effect size across studies, $\mathrm{Chi}^{2}$ a test of significance for heterogeneity, $I^{2}$ a test for heterogeneity where highest level is $100 \%, Z$ a significance test for the weighted average effect size. A low $P$ value or large $\mathrm{Chi}^{2}$ relative to its degree of freedom $(d f)$ provides evidence of heterogeneity of intervention effects. The squares and bars represent the mean values and 99\% CIs of the effect sizes, and the area of the squares reflects the weight of the studies. The diamond represents the combined effect

\section{Secondary Pain-Related Outcomes}

\section{Time from Start of Treatment to First Pain Relief}

Seven studies $[13,15,16,18,20,21,25]$ reported the time of first pain relief, and one of these seven trials was not included in the meta-analysis because of insufficient information to allow for analysis [15]. Compared to the control group, methoxyflurane was shown to significantly shorten the time to first pain relief by an average of $5.29 \mathrm{~min}(95 \% \mathrm{CI}-6.97 \mathrm{~min}$ to -3.62 min; $p<0.00001 ; I^{2}=100 \%$ ) (Fig. $4 \mathrm{a}$ ).

Proportion of Patients Experiencing Pain Relief The proportion of pain relief was assessed in six studies $[13,15,17-20]$. Patients in the methoxyflurane group exhibited higher pain relief rates than the control group (RR 1.41; 95\% CI 1.17-1.70; $p=0.0003 ; I^{2}=85 \%$ ) (Fig. $4 \mathrm{~b}$ ).

\section{Proportion of Patients Administered Rescue Analgesic Medication}

Seven studies [13, 15-18, 20, 21] reported the proportions of patients administered the rescue

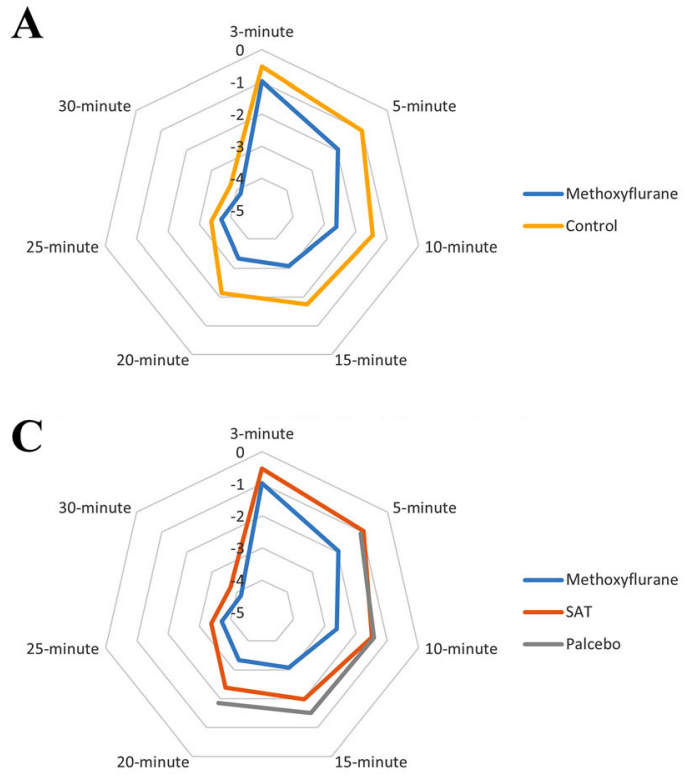

Fig. 3 a Star plot for weighted mean of the change in pain scores across $30 \mathrm{~min}$ at seven time points in methoxyflurane and control groups. b Band plot for weighted mean difference (WMD) of the change in pain severity scores across $30 \mathrm{~min}$ at seven time points $(3 \mathrm{~min}, 5 \mathrm{~min}, 10 \mathrm{~min}$, $15 \mathrm{~min}, 20 \mathrm{~min}, 25 \mathrm{~min}$, and $30 \mathrm{~min}$ ) between methoxyflurane versus control. c Star plot for weighted mean of the change in pain scores across $30 \mathrm{~min}$ at seven
B

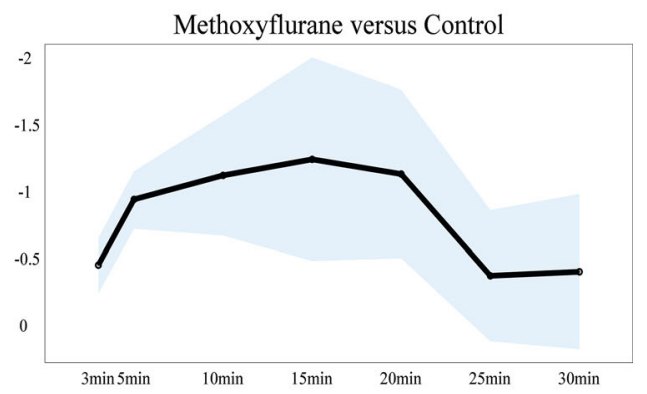

D

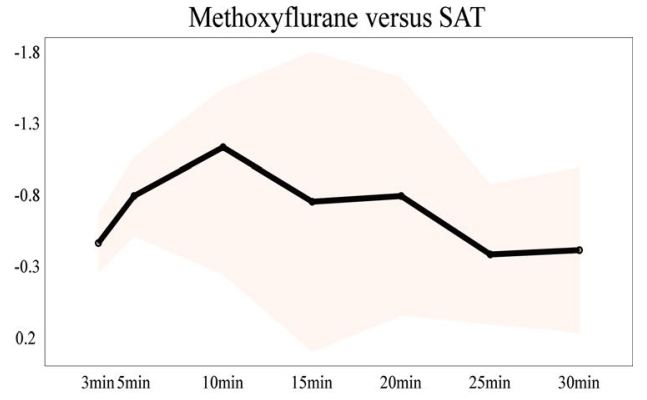

time points in methoxyflurane, placebo, and SAT groups. d Band plot for weighted mean difference (WMD) of the change in pain severity scores across $30 \mathrm{~min}$ at seven time points $(3 \mathrm{~min}, 5 \mathrm{~min}, 10 \mathrm{~min}, 15 \mathrm{~min}, 20 \mathrm{~min}, 25 \mathrm{~min}$, and $30 \mathrm{~min}$ ) between methoxyflurane versus SAT. SAT standard analgesic treatment; pooled estimates of the WMD for each time point are represented by the dark line and $99 \%$ CIs are represented by surrounding shaded region 


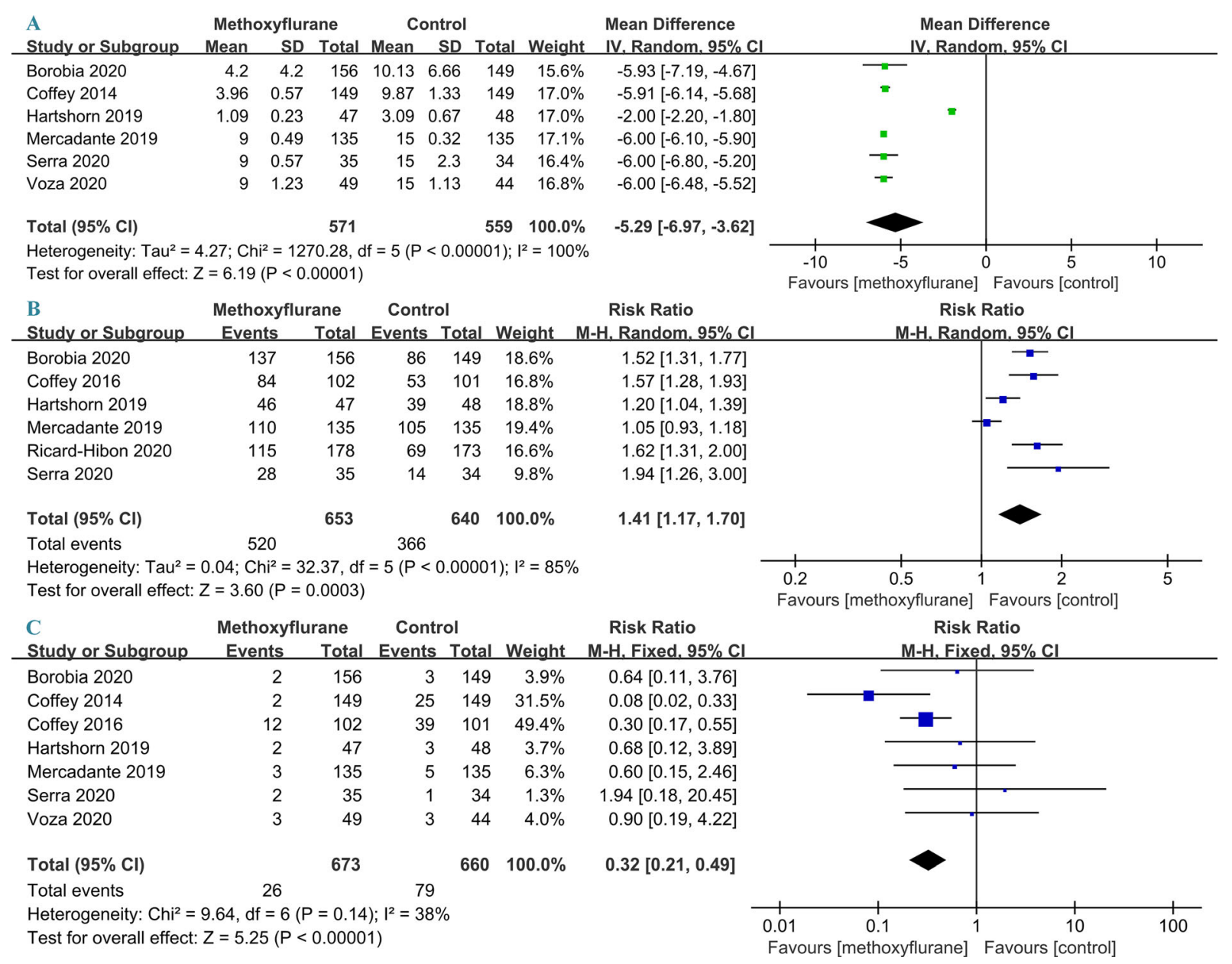

Fig. 4 Forest plots of secondary outcomes associated with pain. a Time of first pain relief; $\mathbf{b}$ proportion of patients experiencing pain relief until their departure from the emergency department; $\mathbf{c}$ proportion of patients who received rescue analgesic medication before discharge. SD standard deviation, IV inverse-variance method, $\mathrm{M}-\mathrm{H}$ the Mantel-Haenszel method, $\mathrm{Tau}^{2}$ a variance of the effect size across studies, $\mathrm{Chi}^{2}$ a test of significance for

analgesic medication before discharge, and all studies had complete data to allow statistical analysis. Compared to the control group, inhaled methoxyflurane significantly reduced the proportion of patients administered the rescue analgesic medication (RR 0.32; 95\% CI 0.21-0.49; $p<0.00001 ; I^{2}=38 \%$ ) (Fig. 4c).

heterogeneity, $I^{2}$ a test for heterogeneity where highest level is $100 \%, Z$ a significance test for the weighted average effect size. A low $p$ value or large $\mathrm{Chi}^{2}$ relative to its degree of freedom $(d f)$ provides evidence of heterogeneity of intervention effects. The squares and bars represent the mean values and $95 \%$ CIs of the effect sizes. The diamond represents the combined effect

\section{Other Secondary Outcomes}

\section{Proportions of Patients, Physicians, or Nurses Who Rated Satisfaction as Excellent, Very Good, or Good}

For therapeutic satisfaction, eight studies $[13,15-21]$, seven studies [15-21], and four studies $[15-17,19]$ reported the proportion of patients, physicians, and nurses that rated it as excellent, very good, or good, respectively. One study [16] was excluded because its data were 


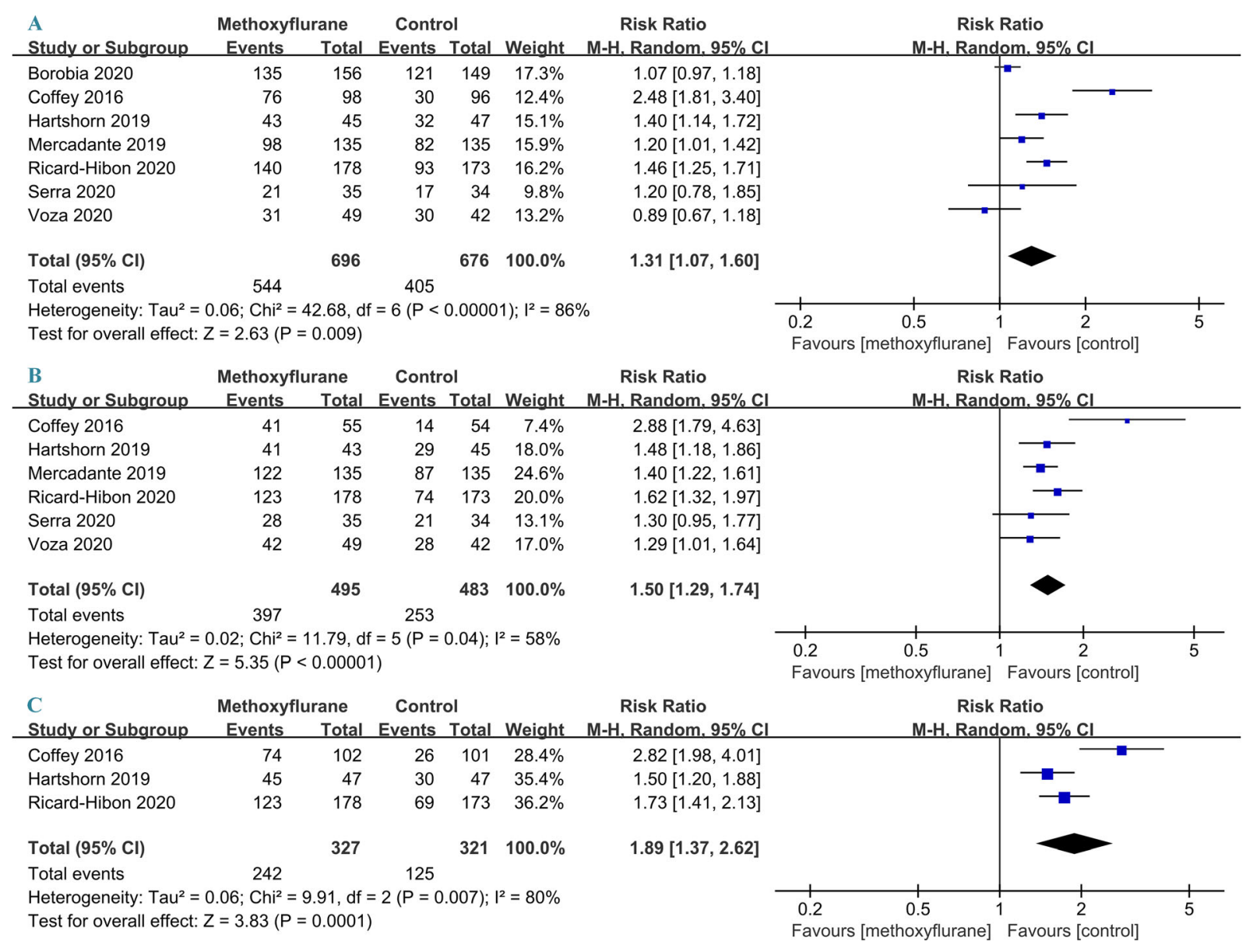

Fig. 5 Forest plot of the proportion of different evaluators for satisfaction assessment who rated as excellent, very good, or good. a Patient assessment; b physician assessment; c research nurse assessment. $M-H$ the Mantel-Haenszel method, $\mathrm{Tau}^{2}$ a variance of the effect size across studies, $\mathrm{Chi}^{2}$ a test of significance for heterogeneity, $I^{2}$ a test for heterogeneity where highest level is $100 \%, Z$ a

not available in an extractable format. Compared to the control group, the overall efficacy of methoxyflurane was rated excellent, very good, or good by significantly more patients in the methoxyflurane group (RR 1.31; 95\% CI $\left.1.07-1.60 ; p=0.009 ; I^{2}=86 \%\right)$. Moreover, significantly more physicians (RR $1.50 ; 95 \%$ CI $\left.1.29-1.74 ; p<0.00001 ; I^{2}=58 \%\right)$ and nurses (RR 1.89; 95\% CI 1.37-2.62; $p=0.0001$; $\left.I^{2}=80 \%\right)$ rated the practicality of using methoxyflurane as excellent, very good, or good when compared to the control (Fig. 5). significance test for the weighted average effect size. A low $p$ value or large $\mathrm{Chi}^{2}$ relative to its degree of freedom $(d f)$ provides evidence of heterogeneity of intervention effects. The squares and bars represent the mean values and 95\% CIs of the effect sizes. The diamond represents the combined effect

\section{Methoxyflurane-Related TEAEs}

Eight studies [13-19, 21] evaluated the total incidence of TEAEs, but one of these trials was not included because raw data were not presented in the manuscript [14]. In the meantime, the most common adverse events following methoxyflurane administration, namely, dizziness, somnolence, feeling drunk, and headache, were reported by seven (1386 patients) [13, 15, 17-21], six (1295 patients) [13, 15, 17-20], four (809 patients) [17-19, 21], and four (921 patients) [15, 17-19] of the included trials, respectively. 
The risk of total TEAEs after methoxyflurane administration increased three-fold (RR 3.09; $95 \%$ CI $1.72-5.57 ; I^{2}=87 \%$ ), and there was a statistically significant difference when compared to the control $(p=0.0002)$ (eFig. 2A). Pooled results showed a significantly elevated risk of dizziness (RR 4.12; 95\% CI 2.69-6.29; $\left.I^{2}=0 \% ; p<0.00001\right)$, somnolence (RR 3.60; 95\% CI 1.84-7.07; $\left.I^{2}=0 \% ; p=0.0002\right)$, and feeling drunk (RR 5.43; 95\% CI 2.21-13.89; $\left.I^{2}=0 \% ; p=0.0004\right)$ in patients administered methoxyflurane, when compared to those not administered methoxyflurane. However, we found similar rates of headache (RR 1.26 [95\% CI 0.81-1.95]; risk difference, $2 \%$ [95\% CI - 2 to $5 \%] ; I^{2}=0 \%$ ) between those receiving and those not receiving methoxyflurane (eFig. 2B). Pooled results of TEAEs grouped by system organ $(p>0.05)$ and remaining occasional symptoms $(p>0.05)$ are presented in supplementary material eFigs. 3 and 4.

\section{Sensitivity and Subgroup Analysis}

Neither of the sensitivity analyses, one excluding the studies with a high risk of bias and the other excluding the results of the PenASAP trial [19], changed the robustness of estimates or conclusions for any outcomes of high heterogeneity. However, results of the sensitivity analysis suggest that the open-label studies were probably identified as the most dominant sources of heterogeneity for this research (supplementary material eTables $3 \mathrm{~A}$ and $4 \mathrm{~A}$ ).

Our pre-specified subgroup analysis indicated that heterogeneity may be attributed to the age subgroup and the control group intervention methods. A pre-specified subgroup analysis comparing the change in pain intensity score at 15 and $20 \mathrm{~min}$ after the start of treatment on inhaled normal saline and SAT found the intervention of the control group to be an effect modifier. When excluding the data for normal saline group, subgroup analysis changed the significant overall effect of pain reduction to insignificant at $15 \mathrm{~min}[13,18,21]$ (WMD $-0.73 ; 99 \%$ CI -1.78 to $0.32 ; p=0.07)$ and $20 \min [13,18,21]$ (WMD - 0.77; 99\% CI -1.60 to $0.07 ; p=0.02>0.01$ ) (Fig. $3 c$, d); in other words, there was no significant improvement in pain intensity at $15 \mathrm{~min}$ and $20 \mathrm{~min}$ for the group administered methoxyflurane when compared to SAT (supplementary material eTable 3B). Subsequent subgroup analysis for secondary pain-related outcomes showed that the superiority of methoxyflurane was further narrowed when compared to SAT (the $p$ values were close to the threshold). The different onset time of the two analgesia methods might explain why the overall analgesic benefit of methoxyflurane is not superior to SAT (WMD $-6.00 \mathrm{~min} ; \quad 99 \%$ CI -6.10 to -5.90 ; $p<0.0001)[13,18,20,21]$. Interestingly, adolescents were shown to exhibit better tolerance to methoxyflurane when compared to adults because of higher satisfactory level (RR 1.40 vs RR 1.29) and lower TEAEs incidence (RR 1.39 vs RR 4.45) was observed according to the results of another pre-defined subgroup analysis (supplementary material eTable $4 \mathrm{~B}$ ).

\section{Quality of Evidence}

Table 2 shows the summary of findings for all outcomes including the certainty of evidence. The quality of evidence was downgraded by the high risk of bias, serious inconsistency with high heterogeneity $\left(I^{2}>50 \%\right)$, or serious imprecision with wide $\mathrm{CI}$ in the results. The quality of evidence was low or very low in most outcomes. The outcome of nurses' satisfaction assessment was the only one that exhibited a moderate quality of evidence.

\section{DISCUSSION}

Our findings show that inhaled methoxyflurane compared with control was significantly associated with a statistically significant but clinically unimportant improvement in pain relief for patients with trauma-associated pain during the first $20 \mathrm{~min}$, and without lasting effects at $25 \mathrm{~min}$ and $30 \mathrm{~min}$. Although patients and their healthcare providers exhibited a high level of methoxyflurane treatment satisfaction, methoxyflurane significantly increased the risk of non-serious TEAEs, especially dizziness, somnolence, and feeling drunk. These results 
Table 2 GRADE summary of findings

\begin{tabular}{|c|c|c|c|c|c|c|c|}
\hline Outcomes & $\begin{array}{l}\text { No. of } \\
\text { participants } \\
\text { (studies) }\end{array}$ & $\begin{array}{l}\text { Risk of } \\
\text { bias }\end{array}$ & Inconsistency & Indirectness & Imprecision & $\begin{array}{l}\text { Publication } \\
\text { bias }\end{array}$ & $\begin{array}{l}\text { Certainty } \\
\text { of the } \\
\text { evidence }\end{array}$ \\
\hline
\end{tabular}

Primary outcome

Change in pain intensity score within $30 \mathrm{~min}$ after the start of treatment

\begin{tabular}{|c|c|c|c|c|c|c|}
\hline At $3 \mathrm{~min}$ & $\begin{array}{l}668(3 \\
\text { RCTs) }\end{array}$ & $\begin{array}{l}\text { Very } \\
\text { serious }^{\text {a }}\end{array}$ & Not serious & Not serious & Serious ${ }^{c}$ & None \\
\hline At $5 \mathrm{~min}$ & $\begin{array}{r}1264(6 \\
\text { RCTs) }\end{array}$ & Serious ${ }^{a}$ & Not serious & Not serious & Serious ${ }^{c}$ & None \\
\hline At $10 \mathrm{~min}$ & $\begin{array}{r}1264(6 \\
\text { RCTs) }\end{array}$ & Serious ${ }^{\mathrm{a}}$ & Serious $^{\mathrm{b}}$ & Not serious & Serious ${ }^{c}$ & None \\
\hline At $15 \mathrm{~min}$ & $\begin{array}{r}1264(6 \\
\text { RCTs) }\end{array}$ & Serious ${ }^{a}$ & Serious $^{\mathrm{b}}$ & Not serious & Serious ${ }^{c}$ & None \\
\hline At $20 \mathrm{~min}$ & $\begin{array}{c}1264(6 \\
\text { RCTs) }\end{array}$ & Serious ${ }^{a}$ & Serious $^{\mathrm{b}}$ & Not serious & Serious $^{c}$ & None \\
\hline At $25 \mathrm{~min}$ & $\begin{array}{l}363(2 \\
\text { RCTs })\end{array}$ & $\begin{array}{l}\text { Very } \\
\text { serious }^{\mathrm{a}}\end{array}$ & Serious $^{b}$ & Not serious & Serious $^{c}$ & None \\
\hline At $30 \mathrm{~min}$ & $\begin{array}{l}363(2 \\
\text { RCTs })\end{array}$ & $\begin{array}{l}\text { Very } \\
\text { serious }^{\mathrm{a}}\end{array}$ & Not serious & Not serious & Serious $^{c}$ & None \\
\hline
\end{tabular}

Secondary pain-related outcomes

\begin{tabular}{|c|c|c|c|c|c|c|c|}
\hline $\begin{array}{l}\text { Time from the } \\
\text { start of } \\
\text { treatment to first } \\
\text { pain relief }\end{array}$ & $\begin{array}{c}1130(6 \\
\text { RCTs) }\end{array}$ & Serious $^{\mathrm{a}}$ & Very serious $^{b}$ & Not serious & Not serious & None & $\begin{array}{l}\oplus \bigcirc \bigcirc \bigcirc \\
\text { Very low }\end{array}$ \\
\hline $\begin{array}{l}\text { Proportion of } \\
\text { patients } \\
\text { experiencing } \\
\text { pain relief }\end{array}$ & $\begin{array}{c}1293(6 \\
\text { RCTs) }\end{array}$ & Serious $^{\mathrm{a}}$ & Serious ${ }^{b}$ & Not serious & Not serious & None & $\begin{array}{c}\oplus \oplus \bigcirc \bigcirc \\
\text { Low }\end{array}$ \\
\hline $\begin{array}{l}\text { Proportion of } \\
\text { patients } \\
\text { administered } \\
\text { rescue analgesic } \\
\text { medication }\end{array}$ & $\begin{array}{c}1333(7 \\
\text { RCTs) }\end{array}$ & Serious $^{\mathrm{a}}$ & Serious $^{\mathrm{b}}$ & Not serious & Not serious & None & $\begin{array}{c}\oplus \oplus \bigcirc \bigcirc \\
\text { Low }\end{array}$ \\
\hline Proportions of patie & nts, physicia & r nurses & ho rated satisfa & ion as excelle & , very good, & good & \\
\hline $\begin{array}{l}\text { Proportion of } \\
\text { patients }\end{array}$ & $\begin{array}{c}1372(7 \\
\text { RCTs })\end{array}$ & Serious $^{\mathrm{a}}$ & Serious $^{b}$ & Not serious & Not serious & None & $\begin{array}{c}\oplus \oplus \bigcirc \bigcirc \\
\text { Low }\end{array}$ \\
\hline $\begin{array}{l}\text { Proportion of } \\
\text { physicians }\end{array}$ & $\begin{array}{l}978 \text { (6 } \\
\text { RCTs) }\end{array}$ & Serious $^{\mathrm{a}}$ & Serious $^{b}$ & Not serious & Not serious & None & $\begin{array}{c}\oplus \oplus \bigcirc \bigcirc \\
\text { Low }\end{array}$ \\
\hline
\end{tabular}


Table 2 continued

\begin{tabular}{|c|c|c|c|c|c|c|c|}
\hline Outcomes & $\begin{array}{l}\text { No. of } \\
\text { participants } \\
\text { (studies) }\end{array}$ & $\begin{array}{l}\text { Risk of } \\
\text { bias }\end{array}$ & Inconsistency & Indirectness & Imprecision & $\begin{array}{l}\text { Publication } \\
\text { bias }\end{array}$ & $\begin{array}{l}\text { Certainty } \\
\text { of the } \\
\text { evidence }\end{array}$ \\
\hline $\begin{array}{l}\text { Proportion of } \\
\text { nurses }\end{array}$ & $\begin{array}{l}648(3 \\
\text { RCTs) }\end{array}$ & $\begin{array}{l}\text { Not } \\
\text { serious }\end{array}$ & Serious $^{\mathrm{b}}$ & Not serious & Not serious & None & $\begin{array}{l}\oplus \oplus \oplus \bigcirc \\
\text { Moderate }\end{array}$ \\
\hline \multicolumn{8}{|c|}{ Methoxyflurane-related TEAEs } \\
\hline $\begin{array}{l}\text { Total incidence of } \\
\text { TEAEs }\end{array}$ & $\begin{array}{c}1615(7 \\
\text { RCTs) }\end{array}$ & Serious $^{a}$ & Serious $^{\mathrm{b}}$ & Not serious & Serious $^{c}$ & None & $\begin{array}{l}\oplus \bigcirc \bigcirc \bigcirc \\
\text { Very low }\end{array}$ \\
\hline Dizziness & $\begin{array}{c}1386(7 \\
\text { RCTs) }\end{array}$ & Serious $^{a}$ & Not serious & Not serious & Serious $^{c}$ & None & $\begin{array}{c}\oplus \oplus \bigcirc \bigcirc \\
\text { Low }\end{array}$ \\
\hline Somnolence & $\begin{array}{c}1295(6 \\
\text { RCTs) }\end{array}$ & Serious $^{\mathrm{a}}$ & Not serious & Not serious & Serious $^{c}$ & None & $\begin{array}{c}\oplus \oplus \bigcirc \bigcirc \\
\text { Low }\end{array}$ \\
\hline Feeling drunk & $\begin{array}{l}809(4 \\
\text { RCTs })\end{array}$ & Serious $^{a}$ & Not serious & Not serious & Serious $^{c}$ & None & $\begin{array}{c}\oplus \oplus \bigcirc \bigcirc \\
\text { Low }\end{array}$ \\
\hline Headache & $\begin{array}{l}921(4 \\
\text { RCTs })\end{array}$ & Serious $^{\mathrm{a}}$ & Not serious & Not serious & Serious $^{c}$ & None & $\begin{array}{c}\oplus \oplus \bigcirc \bigcirc \\
\text { Low }\end{array}$ \\
\hline
\end{tabular}

GRADE Grading of Recommendations, Assessment, Development and Evaluation, No. number, RCTs randomized controlled trials, TEAEs treatment-emergent adverse events

a Downgraded because of the studies with high risk of bias (open-label trial)

${ }^{b}$ Downgraded because of substantial statistical heterogeneity of $I^{2}>50 \%$

${ }^{c}$ Downgraded because of a wide confidence interval of the results

were still robust in sensitivity analysis by excluding the open-label studies, which had a high risk of bias. Important to note is that superiority of the analgesic advantage of methoxyflurane was weak and not particularly pronounced when compared to SAT in our predefined subgroup analysis; conversely, inhaled methoxyflurane was significantly associated with superior and faster pain relief for patients with trauma-associated pain when compared to inhaled normal saline. These findings help to inform one of the most controversial issues; that is, whether inhaled methoxyflurane implements fast and efficient pain management in trauma patients [25].

Pain is one of the most common complications that requires prompt management in emergency medicine [2]. Approximately $60-90 \%$ of the patients in the ED present with acute trauma pain, which is one of the main reasons why patients seek treatment [43, 44].
However, there are no consolidated pain management practices, and acute postoperative pain is still a problem for clinicians [45]. Methoxyflurane is a halogenated ether that is administered through a portable inhaler [12], and the minimum alveolar concentration (MAC) value of methoxyflurane $(0.16 \%)$ was the smallest compared to sevoflurane $(2.00 \%)$, isoflurane $(1.15 \%)$, and desflurane $(6.00 \%)$. It has a rapid analgesic effect and is recommended as an emergency treatment option for patients with trauma and associated pain. Previously, the relationship between inhaled methoxyflurane and clinical outcomes of trauma pain had been elucidated by observational studies and some review studies of non-quantitative analysis. Recently, data from multicenter RCTs has significantly expanded the evidence base, but yielded discrepant results. Borobia et al. [13] reported that pain relief for patients in the methoxyflurane treatment group was superior 
compared to that of individuals in the standard therapy group. However, their conclusions were seemingly inconsistent with another several trials, and this inconsistency was more conspicuous in safety findings [14, 20, 21]. Moreover, methoxyflurane has not been widely recognized and there is no global consensus for its use as a therapeutic option $[25,26]$. Therefore, an objective meta-analysis study should be performed on the basis of the findings of the current RCT studies.

In this meta-analysis, we comprehensively assessed the analgesic capacity of methoxyflurane through the change in pain intensity at multiple time points, the time to first pain relief, the first pain relief rate, and the rescue analgesia rate. Although pain scores reported by patients are subjective, the other three metrics can be used as objective complementary items for assessing pain intensity [46]. A lower rescue analgesia rate or a higher first pain relief rate may indicate a lower pain intensity; and in terms of pain score, the VAS and NRS were used as the evaluation method for all included studies, which is very important for reducing clinical heterogeneity [46, 47]. Although the aforementioned factors guarantee data integrity and objectivity in our study, the reduction range of mean difference in pain intensity between the two groups within the first $20 \mathrm{~min}$ at different time points was from 0.9 to 1.2 points, which is likely to only represent a marginal clinically relevant improvement. Studies have reported that a clinically meaningful difference in efficacy between two treatments should be at least 1.3 points on NRS and 1.5 points for older ED patients [39, 40]. However, there is no consensus with regard to the minimum clinically important difference in pain intensity, with marked differences between studies $[48,49]$. On the basis of the aforementioned reasons, and considering the significantly quicker time to first pain relief and the favorable patient- and health personnel-reported assessments of satisfaction, we concluded that methoxyflurane inhalation is a faster pain reliever, is easy to administer, and is a potentially effective analgesic regimen for traumatic pain management in emergency settings; however, caution is warranted in its use.
Our findings demonstrate an increased risk of TEAEs, especially central nervous system-type reactions such as dizziness, somnolence, and feeling drunk that are associated with the administration of methoxyflurane [24]. This finding is consistent with that of most current RCTs examining the efficacy of methoxyflurane in trauma pain $[14-17,20,21]$. The majority of these adverse events were transient, mild, and resolved within the same day [13]. Laboratory tests performed shortly after methoxyflurane administration also revealed no evidence of nephrotoxicity or hepatotoxicity $[13,50]$. However, the net analgesic effect of methoxyflurane realized should be one of the directions of future translational medicine research. The net analgesic effect is strongly associated with a significant reduction in methoxyflurane-associated adverse drug reactions [50]. As it is with the multimodal analgesia principle, it may be suitable to add aromatic adjuvant drugs (e.g., lemon, lavender, and rose) in the inhalation device in order to alleviate the central nervous symptoms $[51,52]$.

In addition to being safe, the cost-effective implications of methoxyflurane should also be considered [24]. Some clinicians may not administer methoxyflurane because of the high costs and a lack of clear clinical benefits, while others may choose to administer methoxyflurane for traumas that are easy to treat (e.g.,, dislocations and fractures) [24]. It has been finitely documented that the administration of inhaled methoxyflurane reduces the use of human resources and consumables compared to SAT [24, 53]. For example, Fabbri et al. suggested that the use of inhaled methoxyflurane compared with intravenously administered paracetamol plus intravenously administered morphine would lead to a reduced use of human resources and consumables, with a lower cost per process of more than $30 €$ (not considering the cost of the device) [24]. Another study showed the overall cost of methoxyflurane use is $86 €$ (considering the staff costs and the cost of device). In general, the use of methoxyflurane will be a potential saving of $96 €$ for each patient with upper limb/shoulder injuries [54]. However, studies included in this meta-analysis did not present any pharmaco- 
economic related data. Therefore, it could be one of the key reasons contributing to the nonroutine use and calling into question of methoxyflurane in the world.

Although sensitivity analyses revealed that effect estimates were robust, it is possible that certain subgroups of patients may benefit less from methoxyflurane. Our subgroup analyses comparing the effect estimates for methoxyflurane and SAT showed that methoxyflurane did not confer additional clinical benefits for patients beyond $10 \mathrm{~min}$ after treatment; that is, the advantages of methoxyflurane in traumatic analgesia may be minor and limited compared to SAT. This finding was confirmed by the subsequent subgroup analyses of satisfaction assessment and TEAE incidence. This difference may be attributed to the time to onset of the two analgesic methods [48]. These results contrast with those of a previous trial [13], which suggested that methoxyflurane has a superior efficacy when compared to the SAT. The results, however, have only allowed us to determine that speed of methoxyflurane action is faster. Moreover, we found that adolescents exhibited better tolerance to methoxyflurane when compared to adults according to the results of another pre-defined subgroup analysis. This underlying phenomenon could be attributed to the fact that teenagers are more susceptible to the distinctive fruity odor of methoxyflurane [17]. More studies should evaluate the role of methoxyflurane in populations of different ages.

The strengths of this meta-analysis include a pre-registered protocol, the comprehensive search strategy, and conservative GRADE assessment of certainty of evidence. The results were cautiously interpreted in the context of clinically important differences [32, 55, 56], allowing a meaningful estimate of the efficacy of methoxyflurane. Additionally, the adjusted statistical threshold for primary outcomes served to reduce the risk of type I error and multiple testing bias $[32,38]$. Finally, the sensitivity analysis, by excluding a study with potential multiple risks (e.g., industry-sponsored), revealed that the effect estimates were robust, as the excluded data did not significantly influence the initial analysis.
However, there were several notable limitations. First, evidence for almost all outcomes was of low or very low quality because of high risk of bias, serious inconsistency, or imprecision in the results. A significant contributor to this poor quality of evidence is the open-label study, which represents an intrinsic bias. Although a double-dummy design could result in the delayed administration of the active drug and a prolonged pain duration for the traumatic patient, rigorous blind studies as designed by Coffey et al. are still feasible $[15,16]$. Second, the current effect indicators could not evaluate the net effect of methoxyflurane. In future studies, a new comprehensive evaluation system should be established to measure the analgesic benefits and side effects of methoxyflurane. Third, we were unable to perform a publication bias test because of the small number of included studies. Finally, as a result of the small number of included trials and low quality of evidence, the findings of comparison between methoxyflurane and SAT in traumatic patients are not conclusive. With the current available data, however, the preponderance of evidence of methoxyflurane is only reflected in rapid analgesia. More adequately designed head-to-head studies are needed to assess the therapeutic differences in the efficacy of methoxyflurane vs SAT in patients with trauma pain.

\section{CONCLUSIONS}

In urgent situations without effective therapy, our systematic review and meta-analysis provides low-quality evidence that methoxyflurane may be cautiously considered as a simple, rapidly acting, and effective therapeutic option for acute trauma pain, despite the higher incidence of non-serious central nervous side effects. However, we cannot draw conclusions with enough certainty that inhaled methoxyflurane has a superior efficacy to SAT. More clinical trials focusing on the net effect of methoxyflurane vs SAT in different age populations should be performed. 


\section{ACKNOWLEDGEMENTS}

Funding. This work was supported by Provincial Developmental Fund of Traditional Chinese Medicine-Key Discipline of TCM (Oncology of TCM) [2100601]. The journal's Rapid Service Fee was funded by the authors.

Authorship. All named authors meet the International Committee of Medical Journal Editors (ICMJE) criteria for authorship for this article, take responsibility for the integrity of the work as a whole, and have given their approval for this version to be published.

Authorship Contributions. Hong Liu: Literature search, Assessment of bias, Writing-original draft, Validation. Xi Fu: Literature search, Assessment of bias, Writing-original draft, Validation. Yi-Feng Ren: Conceptualization, Assessment of bias, Writing-review \& editing, Validation. Shi-Yan Tan: Data collection, Validation. Si-Rui Xiang: Data collection, Validation. Chuan Zheng: Data analysis, Resources, Validation. Feng-Ming You: Data analysis, Methodology, Resources, Validation. Wei Shi: Conceptualization, Assessment of bias, Writingreview \& editing, Validation. Lin-Jiong Li: Conceptualization, Methodology, Writing-original draft.

Disclosures. Hong Liu, Xi Fu, Yi-Feng Ren, Shi-Yan Tan, Si-Rui Xiang, Chuan Zheng, FengMing You, Wei Shi and Lin-Jiong Li have nothing to disclose.

Compliance with Ethics Guidelines. This article is based on previously conducted studies and does not contain any new studies with human participants or animals performed by any of the authors. On December 27, 2020, this meta-analysis was registered on the International Prospective Register of Systematic Reviews (CRD42020223000, https://www.crd. york.ac.uk/prospero).

Data Availability. The datasets generated during and/or analyzed during the current study are available from the corresponding author on reasonable request.

Open Access. This article is licensed under a Creative Commons Attribution-NonCommercial 4.0 International License, which permits any non-commercial use, sharing, adaptation, distribution and reproduction in any medium or format, as long as you give appropriate credit to the original author(s) and the source, provide a link to the Creative Commons licence, and indicate if changes were made. The images or other third party material in this article are included in the article's Creative Commons licence, unless indicated otherwise in a credit line to the material. If material is not included in the article's Creative Commons licence and your intended use is not permitted by statutory regulation or exceeds the permitted use, you will need to obtain permission directly from the copyright holder. To view a copy of this licence, visit http://creativecommons.org/licenses/by$\mathrm{nc} / 4.0 /$.

\section{REFERENCES}

1. Albrecht E, Taffe P, Yersin B, et al. Undertreatment of acute pain (oligoanalgesia) and medical practice variation in prehospital analgesia of adult trauma patients: a 10 years retrospective study. $\mathrm{Br} \mathrm{J}$ Anaesth. 2013;110:96-106.

2. Todd KH, Ducharme J, Choiniere M, et al. Pain in the emergency department: results of the pain and emergency medicine initiative (PEMI) multicenter study. J Pain. 2007;8:460-6.

3. Cordell WH, Keene KK, Giles BK, et al. The high prevalence of pain in emergency medical care. Am J Emerg Med. 2002;20:165-9.

4. Newcomb P, Wilson M, Baine R, et al. Influences on patient satisfaction among patients who use emergency departments frequently for pain-related complaints. J Emerg Nurs. 2017;43:553-9.

5. Brown T, Shetty A, Zhao DF, et al. Association between pain control and patient satisfaction outcomes in the emergency department setting. Emerg Med Australas. 2018;30:523-9. 
6. Krauss BS, Calligaris L, Green SM, Barbi E. Current concepts in management of pain in children in the emergency department. Lancet. 2016;387:83-92.

7. Smith BC, Vigotsky AD, Apkarian AV, Schnitzer TJ. Temporal factors associated with opioid prescriptions for patients with pain conditions in an urban emergency department. JAMA Netw Open. 2020;3: e200802.

8. e Silva LOJ, Scherber K, Cabrera D, et al. Safety and efficacy of intravenous lidocaine for pain management in the emergency department: a systematic review. Ann Emerg Med. 2018;72:135-44 (e3).

9. Todd KH. A review of current and emerging approaches to pain management in the emergency department. Pain Ther. 2017;6:193-202.

10. Motov SM, Khan AN. Problems and barriers of pain management in the emergency department: Are we ever going to get better? J Pain Res. 2008;2:5-11.

11. Smith JE, Rockett M, Creanor S, et al. PAin SoluTions In the Emergency Setting (PASTIES)-patient controlled analgesia versus routine care in emergency department patients with pain from traumatic injuries: randomised trial. BMJ. 2015;350: h2988.

12. Tomlin PJ. Methoxyflurane. Br J Anaesth. 1965;37: 706-9.

13. Borobia AM, Collado SG, Cardona CC, et al. Inhaled methoxyflurane provides greater analgesia and faster onset of action versus standard analgesia in patients with trauma pain: InMEDIATE: a randomized controlled trial in emergency departments. Ann Emerg Med. 2020;75:315-28.

14. Brichko L, Gaddam R, Roman C, et al. Rapid administration of methoxyflurane to patients in the emergency department (RAMPED) study: a randomized controlled trial of methoxyflurane versus standard care. Acad Emerg Med. 2020;28:164-71.

15. Coffey F, Dissmann P, Mirza K, Lomax M. Methoxyflurane analgesia in adult patients in the emergency department: a subgroup analysis of a randomized, double-blind, placebo-controlled study (STOP!). Adv Ther. 2016;33:2012-31.

16. Coffey F, Wright J, Hartshorn S, et al. STOP!: a randomised, double-blind, placebo-controlled study of the efficacy and safety of methoxyflurane for the treatment of acute pain. Emerg Med J. 2014;31:613-8.

17. Hartshorn S, Dissmann P, Coffey F, Lomax M. Lowdose methoxyflurane analgesia in adolescent patients with moderate-to-severe trauma pain: a subgroup analysis of the STOP! study. J Pain Res. 2019;12:689-700.

18. Mercadante S, Voza A, Serra S, et al. Analgesic efficacy, practicality and safety of inhaled methoxyflurane versus standard analgesic treatment for acute trauma pain in the emergency setting: a randomised, open-label, active-controlled, multicentre trial in Italy (MEDITA). Adv Ther. 2019;36:3030-46.

19. Ricard-Hibon A, Lecoules N, Savary D, et al. Inhaled methoxyflurane for the management of trauma related pain in patients admitted to hospital emergency departments: a randomised, double-blind placebo-controlled trial (PenASAP study). Eur J Emerg Med. 2020;27:414-21.

20. Serra S, Voza A, Ruggiano G, et al. Efficacy, practicality, and safety of inhaled methoxyflurane in elderly patients with acute trauma pain: subgroup analysis of a randomized, controlled, multicenter, open-label trial (MEDITA). J Pain Res. 2020;13: 1777-84.

21. Voza A, Ruggiano G, Serra S, et al. Inhaled methoxyflurane versus intravenous morphine for severe trauma pain in the emergency setting: subgroup analysis of MEDITA, a multicenter, randomized, controlled. Open-Label Trial J Pain Res. 2020;13:491-502.

22. EUSEM guidelines for the management of acute pain in emergency situations 2019. Available from: https://eusem.org/images/EUSEM_EPI_GUIDELINES_ MARCH_2020.pdf.

23. Australian Therapeutic Goods administration Approved product information for Penthrox 2016. Available from: https://www.ebs.tga.gov.au/ ebs/picmi/picmirepository.nsf/PICMI?OpenForm\&t= pi\&q=methoxyflurane. Accessed 3 Sept 2018.

24. Fabbri A, Ruggiano G, Garcia Collado S, et al. Role of inhaled methoxyflurane in the management of acute trauma pain. J Pain Res. 2020;13:1547-55.

25. Hartshorn S, Middleton PM. Efficacy and safety of inhaled low-dose methoxyflurane for acute paediatric pain: a systematic review. Trauma. 2019;21: 94-102.

26. Blair HA, Frampton JE. Methoxyflurane: a review in trauma pain. Clin Drug Investig. 2016;36:1067-73.

27. Liberati A, Altman DG, Tetzlaff J, et al. The PRISMA statement for reporting systematic reviews and meta-analyses of studies that evaluate healthcare interventions: explanation and elaboration. BMJ. 2009;339:b2700. 
28. Higgins JP, Altman DG, Gøtzsche PC, et al. The Cochrane Collaboration's tool for assessing risk of bias in randomised trials. BMJ. 2011;343:d5928.

29. Guyatt GH, Oxman AD, Kunz R, et al. Going from evidence to recommendations. BMJ. 2008;336: 1049-51.

30. Guyatt G, Oxman AD, Akl EA, et al. GRADE guidelines: 1. Introduction-GRADE evidence profiles and summary of findings tables. J Clin Epidemiol. 2011;64:383-94.

31. Thorlund K, Walter SD, Johnston BC, Furukawa TA, Guyatt GH. Pooling health-related quality of life outcomes in meta-analysis-a tutorial and review of methods for enhancing interpretability. Res Synth Methods. 2011;2:188-203.

32. Hussain N, Brull R, Noble J, et al. Statistically significant but clinically unimportant: a systematic review and meta-analysis of the analgesic benefits of erector spinae plane block following breast cancer surgery. Reg Anesth Pain Med. 2021;46:3-12.

33. Wan X, Wang W, Liu J, Tong T. Estimating the sample mean and standard deviation from the sample size, median, range and/or interquartile range. BMC Med Res Methodol. 2014;14:135.

34. Higgins JPT, Green S, editors. Cochrane handbook for systematic reviews of interventions, version 5.1. 0. The Cochrane Collaboration. 2011. http:// training.cochrane.org/handbook.

35. Hess AS, Hess JR. Understanding standard deviations and standard errors. Transfusion. 2016;56: 1259-61.

36. DerSimonian R, Laird N. Meta-analysis in clinical trials revisited. Contemp Clin Trials. 2015;45: 139-45.

37. Holm SA. A simple sequentially rejective multiple test procedure. Scand J Stat. 1979;6:65-70.

38. Hussain N, Brull R, Sheehy B, et al. Perineural liposomal bupivacaine is not superior to nonliposomal bupivacaine for peripheral nerve block analgesia. Anesthesiology. 2020;134:147-64.

39. Bijur PE, Latimer CT, Gallagher EJ. Validation of a verbally administered numerical rating scale of acute pain for use in the emergency department. Acad Emerg Med. 2003;10:390-2.

40. Bijur PE, Chang AK, Esses D, Gallagher EJ. Identifying the minimum clinically significant difference in acute pain in the elderly. Ann Emerg Med. 2010;56:517-21 (e1).
41. Egger M, Davey Smith G, Schneider M, Minder C. Bias in meta-analysis detected by a simple, graphical test. BMJ. 1997;315:629-34.

42. Lawati KA, Sharif S, Maqbali SA, et al. Efficacy and safety of tranexamic acid in acute traumatic brain injury: a systematic review and meta-analysis of randomized-controlled trials. Intensive Care Med. 2021;47:14-27.

43. Berben SA, Meijs TH, van Dongen RT, et al. Pain prevalence and pain relief in trauma patients in the accident and emergency department. Injury. 2008;39:578-85.

44. Guéant S, Taleb A, Borel-Kühner J, et al. Quality of pain management in the emergency department: results of a multicentre prospective study. Eur J Anaesthesiol. 2011;28:97-105.

45. Tainter CR. An evidence-based approach to traumatic pain management in the emergency department. Emerg Med Pract. 2012;14:1-26.

46. Park SK, Yoon S, Kim BR, et al. Pre-emptive epidural analgesia for acute and chronic post-thoracotomy pain in adults: a systematic review and meta-analysis. Reg Anesth Pain Med. 2020;45:1006-16.

47. Schoenthaler M, Miernik A, Offner K, et al. The cumulative analgesic consumption score (CACS): evaluation of a new score to describe postsurgical analgesic consumption as a surrogate parameter for postoperative pain and invasiveness of surgical procedures. Int Braz J Urol. 2014;40:330-6.

48. Montassier E, Freund Y. Methoxyflurane may provide faster relief than suboptimal treatment, but not better. Ann Emerg Med. 2020;75:550-1.

49. Olsen MF, Bjerre E, Hansen MD, et al. Pain relief that matters to patients: systematic review of empirical studies assessing the minimum clinically important difference in acute pain. BMC Med. 2017;15:35

50. Dayan AD. Analgesic use of inhaled methoxyflurane: evaluation of its potential nephrotoxicity. Hum Exp Toxicol. 2016;35:91-100.

51. Choi J, Lee JA, Alimoradi Z, Lee MS. Aromatherapy for the relief of symptoms in burn patients: a systematic review of randomized controlled trials. Burns. 2018;44:1395-402.

52. Smeriglio A, Alloisio S, Raimondo FM, et al. Essential oil of Citrus lumia Risso: phytochemical profile, antioxidant properties and activity on the central nervous system. Food Chem Toxicol. 2018;119: 407-16. 
53. Wells C, Adcock L. CADTH Rapid Response Reports. Methoxyflurane for acute pain in the emergency department: a review of clinical effectiveness, costeffectiveness and guidelines. Ottawa (ON): Canadian Agency for Drugs and Technologies in Health; 2018.

54. Young L, Bailey GP, McKinlay JAC. Service evaluation of methoxyflurane versus standard care for overall management of patients with pain due to injury. Adv Ther. 2020;37:2520-7.
55. Ren Y, Shi W, Chen C, et al. Efficacy of dexmedetomidine as an adjuvant to local wound infiltration anaesthesia in abdominal surgery: a meta-analysis of randomised controlled trials. Int Wound J. 2019;16:1206-13.

56. Ren Y, Wei M, Liu H, et al. Efficacy and safety of dexmedetomidine as an adjuvant to local wound infiltration anaesthesia: a meta-analysis with trial sequential analysis of 23 randomised controlled trials. Int Wound J. 2021;18:32-48. 